\title{
Optimisation of Growth Yield and Quality of Strawberry Cultivars through Organic Farming
}

\author{
M. H. A. Rashid \\ Department of Horticulture, Bangladesh Agricultural University, Mymensingh-2202 \\ Corresponding author: harun_hort@bau.edu.bd
}

\begin{abstract}
Adoption of organic farming has been increased which have a reduced impact on environment. An experiment was conducted at the Landscaping section and Laboratory of the Department of Horticulture, Bangladesh Agricultural University, Mymensingh for optimisation of growth, yield and quality of strawberry cultivars through organic farming during the period from October 2017 to March 2018. The experiment comprised two cultivars viz., RU-1 (Festival) and RU-2 (AOG), and eight organic manures viz., control, cowdung, mustard oilcake (MOC), poultry manure, cowdung+MOC, cowdung+poultry manure, MOC+poultry manure, cowdung+MOC+poultry manure. The two-factor experiment was laid out in randomised complete block design with three replications. Significant variation was observed between strawberry cultivars and organic manures in all the parameters studied. Highest growth, yield and quality characters were obtained from Festival except number of runner per plant and TSS content with AOG. Combined application of cowdung+MOC+poultry manure gave the maximum yield (19.14 t/ha) than the other treatments.
\end{abstract}

Key words: AOG, Festival, Growth, Organic manures, TSS

\section{Introduction}

Organic farming is an important agricultural practice that raise plants especially fruits and vegetables without the use of high-yield crop cultivars, synthetic pesticides, herbicides, chemical fertilizers, or plant growth regulators and mechanization (Asami et al., 2003; Abu-Zahra and Tahboub, 2008). Pollution is becoming a serious problem in agricultural regions. For example, various mineral fertilizers and agrochemicals lead to pollution and serious health problems in humans, hence alternative production techniques which employ biological or organic compounds for disease and pest control are needed (Turemis, 2002).

Strawberry (Fragaria virginiana) belonging to the family Rosaceae is one of the most delicious, delicate flavoured, refreshing, and attractive red fruit of the world (Sharma, 2002). It is native to most of the Northern hemisphere including Europe and Great Britain. It is a nutritious, quick growing and exotic fruit in Bangladesh and suitable for adaptation in our cropping pattern. It is usually eaten as raw or used to making ice-creams, jams, jellies, pickles, chocolates, biscuits, cakes and milkshakes. Strawberries are also rich in vitamin $\mathrm{C}$ and total antioxidents and are thus important for human health (Halvorsen et al., 2002). Strawberry produces fruits during November to April (Badiyala and Bhutani, 1990) when most of the fruits are not available which may help to increase the availability of fruits in the lean period of Bangladesh.
Cultivation technique of strawberry is fairly new in Bangladesh whereas cultivation area is increasing day by day. A sustainable variety is needed for the continuous production from year to year. Farmer shows tendency of more chemical fertilization for strawberry production to improve yield. The application of organic manures not only supplies the plants with necessary elements but also plays an important part in the process of enhancing soil fertility by improving its structure and hydro-physical properties, increasing organic matter concentration and reducing the application of synthetic fertilizers (Grandy et al., 2002). Unlike inorganic fertilizers, organic manures have a longer lasting impact on chemical properties of the soil and consequently on the yield of grown crops, even several years after application (Gutser et al., 2005). It is excellent source of nutrients and it could maintain high microbial populationôs activities. In Bangladesh the interest for organic farming has been increased recently. Fruit quality of strawberry is also influenced by agrotechnical treatments i.e., mulching, irrigation, fertilization, crop rotation, intercropping, proper field preparation, planting time, health status and type of seedlings (LaMondia et al., 2002). Sweetness of strawberry is a major problem in Bangladesh. Organically grown strawberry increase total soluble solids (TSS) content, hence produce high quality fruit with sweeter in taste, longer shelf life (by thickening fruit peel) and better flavour (Reganold et al., 2010). 
Various organic manures such as cowdung, compost, vermin compost, mustard oilcake (MOC), green manure and poultry manure are excellent source of organic matters commonly used for crop production (Hasan, 2013; Rahman et al., 2018). Svensson (2002) found that green manure produced, $7,0.8$ and 6.2 $\mathrm{g} /$ plant of $\mathrm{N}, \mathrm{P}$ and $\mathrm{K}$, respectively, while cowdung produced 55, 29 and $52 \mathrm{~g} /$ plant of $\mathrm{N}, \mathrm{P}$ and $\mathrm{K}$, respectively, hence, decomposed cowdung is probably best applied as a source of nutrients before planting. Application of cowdung resulted in an increase in soil mineral elements such as $\mathrm{N}, \mathrm{P}, \mathrm{K}, \mathrm{Fe}, \mathrm{Zn}, \mathrm{Mn}, \mathrm{Cu}, \mathrm{Cd}$ and $\mathrm{Pb}$, while decrease soil $\mathrm{pH}$ was lowered (Abebe, 2001). Mustard oil cake has also unique properties of organic ingredients that make it a favourable fertilizer and even herbicide source. Growers can get both fertilizer and pesticide benefits from mustard meals. It has been shown to control weeds, insect pests, nematodes and pathogens (Boydston et al. 2008; Vaughn et al. 2006; Norsworthy and Meehan 2005). Besides, poultry manures improve soil structures, nutrient retention, aeration, soil moisture holding capacity and water infiltration (Deksissa et al., 2008). It contains high NPK and other essential nutrients that more readily supply $\mathrm{P}$ to plants than other organic manure sources (Garg and Bahla, 2008). Under organic culture, average and marketable yield of strawberry were decreased compared to conventional culture (Lindhard et al., 2000), market conditions resulted in greater returns/ha, since prices were $50 \%$ higher, making the organic system more profitable (Gliessman et al., 1996). However, still a limited work has been done on the single and combined application of organic manures under different strawberry cultivars. The present study was, therefore, undertaken to study the optimisation of growth, yield and quality of strawberry cultivars through organic farming.

\section{Materials and Methods}

The experiment was carried out at the Landscaping section and Laboratory of the Department of Horticulture, Bangladesh Agricultural University, Mymensingh for optimisation of growth, yield and quality of strawberry cultivars through organic farming during the period from October 2017 to March 2018. The experimental site was medium high land belonging to the Old Brahmaputra Floodplain under the Agro-Ecological Zone 9 having non-calcareous dark gray floodplain soil (UNDP and FAO 1988). The soil of the experimental plot was silty loam in texture and neutral $(\mathrm{pH} 7.0)$ in reaction, which is suitable for strawberry production. The experiment comprised two strawberry cultivars viz. $\mathrm{V}_{1}$ : RU-1 (Festival) and $\mathrm{V}_{2}$ : RU-2 (AOG), and eight organic manure treatments viz., $\mathrm{T}_{0}=$ control (no organic manures applied),
$\mathrm{T}_{1}=$ cowdung @ $4 \mathrm{~kg} / \mathrm{m}^{2}, \mathrm{~T}_{2}=$ mustard oilcake (MOC) @ $4 \mathrm{~kg} / \mathrm{m}^{2}, \mathrm{~T}_{3}=$ poultry manure @ $4 \mathrm{~kg} / \mathrm{m}^{2}$, $\mathrm{T}_{4}=$ cowdung+MOC @ 1:1, $\mathrm{T}_{5}=$ cowdung+poultry manure @ 1:1, $\mathrm{T}_{6}=\mathrm{MOC}+$ poultry manure @ 1:1, $\mathrm{T}_{7}=$ cowdung+MOC+poultry manure @ 1:1:1. Thetwo-factor experiment was laid out in randomised complete block design with three replications and altogether 14 treatment combinations in this experiment. Healthy seedlings of two strawberry cultivars were collected from a commercial nursery in Rajshahi. The seedlings of uniform size were transplanted on 14 November 2017 in the evening at a spacing of $50 \mathrm{~cm} \times 30 \mathrm{~cm}$. Each unit plot was $1.0 \mathrm{~m} \mathrm{x}$ $1.0 \mathrm{~m}$ in size, which consist of 6 plants. The spacing of plot to plot was $50 \mathrm{~cm}$ and block to block was $1.0 \mathrm{~m}$. Different organic manure treatments were applied to different unit plots 21 days before planting of seedlings and then it was incorporated into the soil carefully. After transplantation, irrigation, weeding and natural mulching were done as and when necessary. Straw mulch was provided onset of flower formation. The experimental plots were covered with nylon net to protect the fruit from birds. Data were recorded from all 6 plants under each plot on growth parameters viz., plant height $(\mathrm{cm})$, number of leaves and runner per plant, and yield and quality parameters viz., number of fruit per plant, average and total fruit weight (g), length and breadth of fruit $(\mathrm{cm})$, fruit yield $(\mathrm{t} / \mathrm{ha})$, and TSS content (\% brix). Collected data were analyzed statistically using MSTAT computer programme. The significance of difference between pair of means was tested by the least significant differences (LSD) test at $5 \%$ level of probability (Gomez and Gomez, 1984).

\section{Results and Discussion}

\section{Effect of variety}

Statistically significant variation was observed among the strawberry cultivars in terms of all the vegetative growth parameters under study (Table 1). Results indicated that Festival cultivar (RU-1) recorded the highest mean values for plant height $(20.04 \mathrm{~cm})$ and number of leaves per plant (27.60) compared to the lowest plant height $(18.46 \mathrm{~cm})$ and number of leaves per plant (24.83) of AOG cultivar (RU-2). This might be due to the linear increment of the plant height and number of leaves per plant up to the maximum vegetative growth stage (Hasan, 2013). The obtained results seemed to complement with those reported by Shiow et al. (1998). In case of runner production, it was found that AOG produced more runners per plant (3.95) than that of the Festival (3.47). This result indicates that the numbers of runner per plant are not the same for two cultivars and this character might be genetically controlled. 
Table 1. Main effects of variety and organic manures on growth, yield and quality characters of strawberry

\begin{tabular}{|c|c|c|c|c|c|c|c|c|c|}
\hline Treatments & $\begin{array}{l}\text { Plant } \\
\text { height } \\
(\mathrm{cm})\end{array}$ & $\begin{array}{c}\text { No. of } \\
\text { leaves/p } \\
\text { lant }\end{array}$ & $\begin{array}{c}\text { No. of } \\
\text { runner/ } \\
\text { plant }\end{array}$ & $\begin{array}{c}\text { No. of } \\
\text { fruit/plant }\end{array}$ & $\begin{array}{c}\text { Averag } \\
\text { e fruit } \\
\text { weight } \\
(\mathrm{g})\end{array}$ & $\begin{array}{c}\text { Total } \\
\text { fruit } \\
\text { weight } \\
\text { (g/plant) }\end{array}$ & $\begin{array}{l}\text { Length } \\
\text { of fruit } \\
(\mathrm{cm})\end{array}$ & $\begin{array}{c}\text { Breadth } \\
\text { of fruit } \\
(\mathrm{cm})\end{array}$ & $\begin{array}{c}\text { TSS } \\
\text { content } \\
\text { (\%brix) }\end{array}$ \\
\hline \multicolumn{10}{|c|}{ Factor A: Variety } \\
\hline $\mathrm{V}_{1}$ & 20.04 & 27.60 & 3.47 & 18.45 & 12.52 & 235.40 & 2.87 & 2.48 & 6.63 \\
\hline $\mathrm{V}_{2}$ & 18.46 & 24.83 & 3.95 & 16.70 & 11.85 & 202.30 & 2.74 & 2.34 & 7.26 \\
\hline $\mathrm{LSD}_{0.05}$ & 0.072 & 0.375 & 0.065 & 0.181 & 0.070 & 3.79 & 0.032 & 0.019 & 0.049 \\
\hline $\begin{array}{l}\text { Level of } \\
\text { significance }\end{array}$ & $*$ & $*$ & $*$ & $*$ & $*$ & $*$ & $*$ & $*$ & $*$ \\
\hline \multicolumn{10}{|c|}{ Factor B: Organic manures } \\
\hline $\mathrm{T}_{0}$ & 15.43 & 16.88 & 2.41 & 11.55 & 9.95 & 115.20 & 2.14 & 1.71 & 4.32 \\
\hline $\mathrm{T}_{1}$ & 17.89 & 19.93 & 2.78 & 14.67 & 11.21 & 167.00 & 2.52 & 2.13 & 5.47 \\
\hline $\mathrm{T}_{2}$ & 18.61 & 24.08 & 3.40 & 17.43 & 11.85 & 206.80 & 2.75 & 2.35 & 6.17 \\
\hline $\mathrm{T}_{3}$ & 17.89 & 22.67 & 3.18 & 16.43 & 11.52 & 189.50 & 2.61 & 2.24 & 6.87 \\
\hline $\mathrm{T}_{4}$ & 20.40 & 29.12 & 4.11 & 19.17 & 12.81 & 245.80 & 2.98 & 2.59 & 6.51 \\
\hline $\mathrm{T}_{5}$ & 19.95 & 26.42 & 3.55 & 18.28 & 12.37 & 228.10 & 2.83 & 2.47 & 7.80 \\
\hline $\mathrm{T}_{6}$ & 21.08 & 33.25 & 4.51 & 20.88 & 13.39 & 279.10 & 3.14 & 2.70 & 8.69 \\
\hline $\mathrm{T}_{7}$ & 22.75 & 37.35 & 5.70 & 22.15 & 14.38 & 319.20 & 3.46 & 3.07 & 9.74 \\
\hline $\mathrm{LSD}_{0.05}$ & 0.144 & 0.751 & 0.129 & 0.362 & 0.139 & 7.57 & 0.065 & 0.037 & 0.099 \\
\hline $\begin{array}{l}\text { Level of } \\
\text { significance }\end{array}$ & $*$ & $*$ & $*$ & * & * & $*$ & $*$ & $*$ & $*$ \\
\hline
\end{tabular}

*=5\% level of probability, $\mathrm{V}_{1}$ : RU-1 (Festival) and $\mathrm{V}_{2}$ : RU-2 (AOG), $\mathrm{T}_{0}=$ control, $\mathrm{T}_{1}=$ cowdung @ $4 \mathrm{~kg} / \mathrm{m}^{2}, \mathrm{~T}_{2}=\mathrm{mustard}$ oilcake (MOC) @ $4 \mathrm{~kg} / \mathrm{m}^{2}, \mathrm{~T}_{3}=$ poultry manure @ $4 \mathrm{~kg} / \mathrm{m}^{2}, \mathrm{~T}_{4}=$ cowdung+MOC @ 1:1, T $=$ cowdung+poultry manure @ 1:1, $\mathrm{T}_{6}=\mathrm{MOC}+$ poultry manure @ 1:1, T7 $=$ cowdung+MOC+poultry manure @ 1:1:1.

Yield and quality parameters were also significantly influenced by strawberry cultivars (Table 1 and Fig. 1). Festival gave maximum number of fruits per plant (18.45), average fruit weight (12.52 g) and total fruit weight per plant ( $235.4 \mathrm{~g}$ ), whereas the minimum fruits per plant (16.70), average fruit weight $(11.85 \mathrm{~g})$ and total fruit weight per plant (203.3 g) were obtained from AOG. Strawberry plant produced significantly varied number of fruits per plant, average fruit weight and total fruit weight per plant (Atefe et al., 2012). Results indicated that the longest fruit length $(2.87 \mathrm{~cm})$ and breadth $(2.48 \mathrm{~cm})$ were recorded from Festival, while the shortest fruit length $(2.74 \mathrm{~cm})$ and breadth $(2.34 \mathrm{~cm})$ were found from AOG. This might be due to the maximum number of leaves per plant, earlier flower bud initiation, flowering and fruit setting at the mature stage that enables the cultivar Festival enhanced carbohydrates concentration in crown and root at the of fruiting. Morgan (2006) found that final size of berry depends on number of acheneôs formed, which was determined by pollination and fertilization at the time of blooming. The highest fruit yield per hectare $(14.12$ t) was also obtained from Festival, whereas the lowest yield per hectare (12.13 t) was recorded in AOG (Fig. 1). Large size fruit and higher yield closely correlates with the average and total fruit weight which is controlled by dimension of receptacle, number of acheneôs position of fruits on the inflorescence (Hortynski et al., 1991). Maximum brix percentage (7.26) was found in AOG, whereas the minimum brix percentage (6.63) was observed in Festival, which makes the former sweeter than the later cultivar. Total soluble solids (TSS) content of strawberry fruits varies from $4-11 \%$ depending on cultivars and environment (Perkins-Veazie, 1995). 


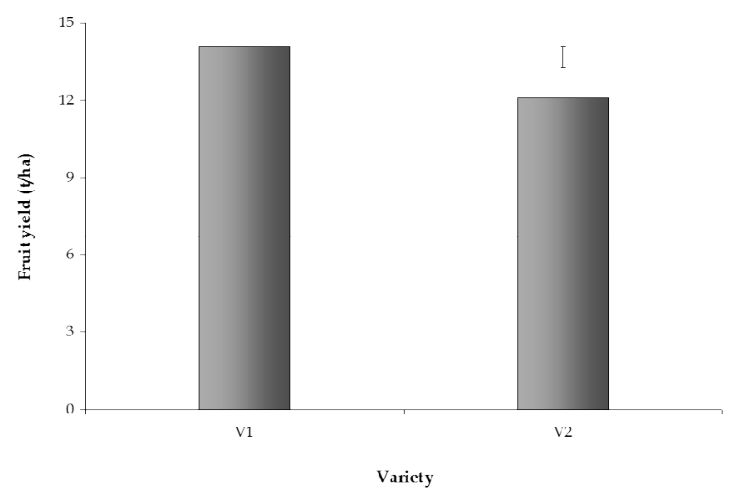

Fig. 1. Main effect of variety on fruit yield ( $t / h a)$ of strawberry. The vertical bar represents LSD at $5 \%$ level of probability

\section{Effect of organic manures}

Organic matters had significant influence on all the vegetative growth parameters of strawberry cultivars viz., plant height, number of leaves and runners per plant (Table 1). Highest plant height $(22.75 \mathrm{~cm})$, number of leaves (37.35) and runners per plant (5.70) were recorded from mixed application of cowdung, MOC and poultry manure $\left(\mathrm{T}_{7}\right)$ followed by plant height $(21.08 \mathrm{~cm})$, number of leaves (33.25) and runners per plant (4.51) with mixed application of MOC and poultry manure $\left(\mathrm{T}_{6}\right)$, while the lowest plant height $(15.43 \mathrm{~cm})$, number of leaves (16.88) and runners per plant (2.41) were recorded from control $\left(\mathrm{T}_{0}\right)$. The utmost augment in vegetative growth attributes of strawberry under these treatments is supported by nitrogen supply especially through organic manures, which accelerates the synthesis of amino acids which might have indirectly exhibited increase in plant height of strawberry (Kumar et al., 2015). Organic manures are also helpful in cell elongation and cell division in meristmatic region of plant, this was due to the production of plant growth substances (IAA and GA). Presence of higher nitrogen (Gopalreddy, 1997; Willrich et al., 1974; Sims, 1987) and phosphorous on MOC compared to other organic manures (Malone et al., 1992) and more water retention capacity may lead to the more plant vegetative growth especially on plant height and number of leaves per plant. Makinde and Ayoola (2012) debriefed that poultry litre supports more of vegetative growth of a plant and for this strawberry plants respond well to poultry manures in terms of plant height. The number of runner can be increased due the presence of plant-growth regulating substances in organic matters and soil biological function improvement (Cristina and Jorge, 2011) through the application of MOC and poultry manure in soil.

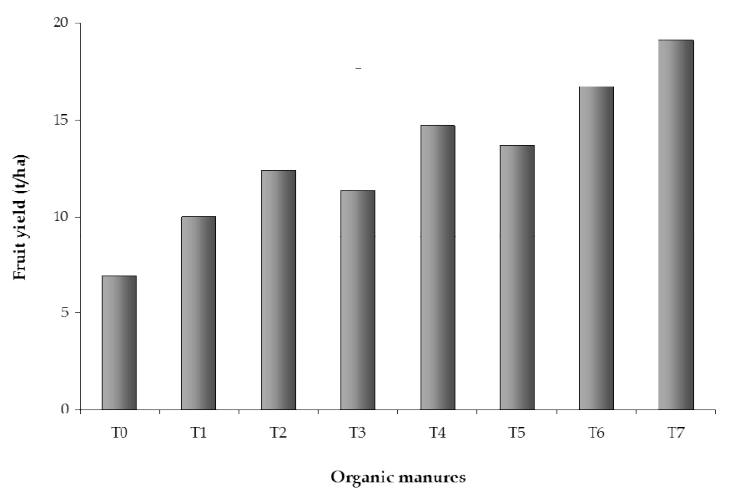

Fig. 2. Main effect of organic manures on fruit yield ( $\mathrm{t} / \mathrm{ha})$ of strawberry. The vertical bar represents LSD at 5\% level of probability

Organic manures had also significant effect on yield and quality characteristics of strawberry under study (Table 1 and Fig. 2). Combined application of cowdung + MOC + poultry manure $\left(\mathrm{T}_{7}\right)$ gave the maximum number of fruits per plant (22.15), average fruit weight $(14.38 \mathrm{~g})$ and total fruit weight per plant (319.2 g), followed by fruits per plant (20.88), average fruit weight $(13.39 \mathrm{~g})$ and total fruit weight per plant $(279.1 \mathrm{~g})$ with mixed application of MOC and poultry manure $\left(\mathrm{T}_{6}\right)$, while the minimum number of fruits per plant (11.55), average fruit weight $(9.95 \mathrm{~g})$ and total fruit weight per plant (115.2 g) were obtained from control $\left(\mathrm{T}_{0}\right)$. This might be due to the higher nutrient content of mixed manure especially and leading to increase uptake of NPK which help the plant to get adequate food and nutrients thus may help to enhance the number and fruit weight (Mamta et al., 2012; Subbaiah et al., 1985). Results showed that the longest fruit length $(3.46 \mathrm{~cm})$ and breadth $(3.07 \mathrm{~cm})$ were recorded from the mixed application of cowdung + MOC + poultry manure $\left(\mathrm{T}_{7}\right)$, followed by mixed application of MOC + poultry manure $\left(\mathrm{T}_{6}\right)$, while the shortest fruit length $(2.14 \mathrm{~cm})$ and breadth $(1.71 \mathrm{~cm})$ were found from control $\left(\mathrm{T}_{0}\right)$. This might be due to the effects of different organic manures on germination, growth, flowering, fruiting and yields of strawberry plants. It was found that mixture of different organic manure application increases the length and breadth in strawberry fruit (Atefe et al., 2012). Fig. 2 indicated that fruit yield per hectare was also found the highest $(19.14 \mathrm{t})$ from cowdung $+\mathrm{MOC}+$ poultry manure $\left(\mathrm{T}_{7}\right)$ followed by $\mathrm{T}_{6}(16.75 \mathrm{t})$, while the lowest $(6.91 \mathrm{t})$ in control $\left(\mathrm{T}_{0}\right)$. A significant difference was observed on fruit yield between mixture of manures and single application of other organic matter source treatments (Pringle et al., 2002; Schopplein et al., 2002). Total soluble solids (TSS) content was recorded highest $(9.74 \%)$ by the application of cowdung + MOC + 
poultry manure $\left(\mathrm{T}_{7}\right)$ followed by treatment comprising of MOC + poultry manure $\left(\mathrm{T}_{6}\right)$ as shown in Table 1 . Such an increase in TSS percentage have arisen due to synergistic effect of nitrogen due to cowdung, MOC and poultry manure on the effect use of these nutrients as well as other in the sugar metabolism of strawberry fruits reported by El-Hamid et al. (2006). All the nutrients significantly reduced the acid content of strawberry fruits over control.

\section{Combined effects variety and organic manures}

Combined effect of strawberry cultivars and organic manures had significant influence on all the vegetative growth parameters under study viz., plant height, number of leaves and runners per plant (Table 2 and Fig. 3). The highest plant height $(24.08 \mathrm{~cm})$ and number of leaves per plant (39.03) was found with Festival and mixed application of cowdung + MOC + poultry manure treatment $\left(\mathrm{V}_{1} \mathrm{~T}_{7}\right)$, followed by 21.42 $\mathrm{cm}$ and 35.67 with AOG with cowdung + MOC + poultry manure $\left(\mathrm{V}_{2} \mathrm{~T}_{7}\right)$ treatment, while the lowest plant height $(14.65 \mathrm{~cm})$ and number of leaves per plant (16.57) were recorded in AOG with control $\left(\mathrm{V}_{2} \mathrm{~T}_{0}\right)$. The study disclosed that Festival cultivar treated with mixture of three manures performed best in terms of plant height and number of leaves per plant. From the experiment it was also observed that plant growth had started to stop which may be due to cease of cell division after flowering (Morgan, 2006). Combination of AOG and cowdung + MOC + poultry manure $\left(\mathrm{V}_{2} \mathrm{~T}_{7}\right)$ gave the maximum number of runner per plant (6.23), followed by 5.17 in Festival with cowdung + MOC + poultry manure $\left(\mathrm{V}_{1} \mathrm{~T}_{7}\right)$, while combination of Festival with control treatment $\left(\mathrm{V}_{1} \mathrm{~T}_{0}\right)$ gave the minimum number of runner per plant (2.30). Turkben et al. (1997) found that lower number of runner production increases the fruit production and improve the quality of strawberry, which might be due to the genetic characters of the cultivars and effects of mixed manures.

Table 2. Combined effects of variety and organic manures on growth, yield and quality characters of strawberry

\begin{tabular}{|c|c|c|c|c|c|c|c|c|c|}
\hline $\begin{array}{c}\text { Treatment } \\
\text { combination }\end{array}$ & $\begin{array}{l}\text { Plant } \\
\text { height } \\
(\mathrm{cm})\end{array}$ & $\begin{array}{c}\text { No. of } \\
\text { leaves/ } \\
\text { plant }\end{array}$ & $\begin{array}{l}\text { No. of } \\
\text { runner/ } \\
\text { plant }\end{array}$ & $\begin{array}{c}\text { No. of } \\
\text { fruit/plant }\end{array}$ & $\begin{array}{l}\text { Average } \\
\text { fruit } \\
\text { weight } \\
\text { (g) }\end{array}$ & $\begin{array}{c}\text { Total } \\
\text { fruit } \\
\text { yield } \\
\text { (g/plant) }\end{array}$ & $\begin{array}{l}\text { Length } \\
\text { of fruit } \\
(\mathrm{cm})\end{array}$ & $\begin{array}{l}\text { Breadth } \\
\text { of fruit } \\
(\mathrm{cm})\end{array}$ & $\begin{array}{c}\text { TSS } \\
\text { content } \\
\text { (\%brix) }\end{array}$ \\
\hline $\mathrm{V}_{1} \mathrm{~T}_{0}$ & 16.20 & 17.20 & 2.30 & 12.53 & 10.23 & 128.3 & 2.20 & 1.75 & 4.15 \\
\hline $\mathrm{V}_{1} \mathrm{~T}_{1}$ & 18.12 & 21.30 & 2.63 & 15.47 & 11.62 & 179.7 & 2.55 & 2.20 & 5.25 \\
\hline $\mathrm{V}_{1} \mathrm{~T}_{2}$ & 19.11 & 25.77 & 3.27 & 18.00 & 12.10 & 217.8 & 2.80 & 2.45 & 5.87 \\
\hline $\mathrm{V}_{1} \mathrm{~T}_{3}$ & 18.53 & 24.50 & 3.07 & 17.00 & 11.81 & 200.8 & 2.66 & 2.34 & 6.60 \\
\hline $\mathrm{V}_{1} \mathrm{~T}_{4}$ & 21.42 & 30.77 & 3.93 & 20.17 & 13.04 & 262.9 & 3.06 & 2.62 & 6.25 \\
\hline $\mathrm{V}_{1} \mathrm{~T}_{5}$ & 20.82 & 27.67 & 3.30 & 19.10 & 12.63 & 241.1 & 2.90 & 2.55 & 7.40 \\
\hline $\mathrm{V}_{1} \mathrm{~T}_{6}$ & 22.02 & 34.53 & 4.07 & 22.23 & 13.70 & 304.6 & 3.17 & 2.75 & 8.18 \\
\hline $\mathrm{V}_{1} \mathrm{~T}_{7}$ & 24.08 & 39.03 & 5.17 & 23.07 & 15.07 & 347.5 & 3.63 & 3.20 & 9.40 \\
\hline $\mathrm{V}_{2} \mathrm{~T}_{0}$ & 14.65 & 16.57 & 2.53 & 10.57 & 9.67 & 102.1 & 2.09 & 1.66 & 4.50 \\
\hline $\mathrm{V}_{2} \mathrm{~T}_{1}$ & 17.67 & 18.57 & 2.93 & 13.87 & 10.80 & 154.4 & 2.50 & 2.06 & 5.70 \\
\hline $\mathrm{V}_{2} \mathrm{~T}_{2}$ & 18.12 & 22.40 & 3.53 & 16.87 & 11.60 & 195.7 & 2.70 & 2.26 & 6.48 \\
\hline $\mathrm{V}_{2} \mathrm{~T}_{3}$ & 17.26 & 20.83 & 3.30 & 15.87 & 11.22 & 178.1 & 2.57 & 2.14 & 7.15 \\
\hline $\mathrm{V}_{2} \mathrm{~T}_{4}$ & 19.37 & 27.47 & 4.30 & 18.17 & 12.58 & 228.6 & 2.91 & 2.56 & 6.78 \\
\hline $\mathrm{V}_{2} \mathrm{~T}_{5}$ & 19.09 & 25.17 & 3.80 & 17.47 & 12.11 & 215.1 & 2.76 & 2.40 & 8.20 \\
\hline $\mathrm{V}_{2} \mathrm{~T}_{6}$ & 20.14 & 31.97 & 4.96 & 19.53 & 13.08 & 253.6 & 3.11 & 2.66 & 9.20 \\
\hline $\mathrm{V}_{2} \mathrm{~T}_{7}$ & 21.42 & 35.67 & 6.23 & 21.23 & 13.70 & 290.9 & 3.29 & 2.95 & 4.15 \\
\hline $\mathrm{LSD}_{0.05}$ & 0.204 & 1.06 & 0.183 & 0.511 & 0.197 & 10.71 & 0.091 & 0.053 & 0.139 \\
\hline $\begin{array}{c}\text { Level of } \\
\text { significance }\end{array}$ & $*$ & $*$ & $*$ & $*$ & $*$ & $*$ & $*$ & $*$ & $*$ \\
\hline
\end{tabular}

*=5\% level of probability, $\mathrm{V}_{1}$ : RU-1 (Festival) and $\mathrm{V}_{2}$ : RU-2 (AOG), $\mathrm{T}_{0}=$ control, $\mathrm{T}_{1}=\mathrm{cowdung} @ 4 \mathrm{~kg} / \mathrm{m}^{2}, \mathrm{~T}_{2}=\mathrm{mustard}$ oilcake (MOC) @ $4 \mathrm{~kg} / \mathrm{m}^{2}, \mathrm{~T}_{3}=$ poultry manure @ $4 \mathrm{~kg} / \mathrm{m}^{2}, \mathrm{~T}_{4}=$ cowdung+MOC @ 1:1, $\mathrm{T}_{5}=$ cowdung+poultry manure @ 1:1, $\mathrm{T}_{6}=\mathrm{MOC}+$ poultry manure @ 1:1, T $=$ cowdung+MOC+poultry manure @ 1:1:1. 
Yield and quality characteristics were also significantly influenced by combined application of strawberry cultivars and organic manures (Table 2 and Fig. 3). Maximum number of fruit per plant (23.07), average fruit weight $(15.07 \mathrm{~g})$ and total fruit weight per plant (347.5 g) were obtained from Festival with mixed application of cowdung + MOC + poultry manure $\left(\mathrm{V}_{1} \mathrm{~T}_{7}\right)$, followed by AOG with mixed application of cowdung + MOC + poultry manure $\left(\mathrm{V}_{2} \mathrm{~T}_{7}\right)$ (21.23, $13.70 \mathrm{~g}$ and $290.9 \mathrm{~g}$, respectively), whereas the minimum number of fruit per plant (10.57), average fruit weight $(9.67 \mathrm{~g})$ and total fruit weight per plant (102.1 g) were recorded from AOG with control treatment $\left(\mathrm{V}_{2} \mathrm{~T}_{0}\right)$. Maximum number and weight of fruit could be due to the effects of mixed manures which reduces the $\mathrm{C}: \mathrm{N}$ ratio (Nagavallemma et al., 2004). Results revealed that the longest fruit length $(3.63 \mathrm{~cm})$ and breadth $(3.20 \mathrm{~cm})$ were recorded from Festival with the mixed application of cowdung + MOC + poultry manure $\left(\mathrm{V}_{1} \mathrm{~T}_{7}\right)$, followed by 3.29 and $2.95 \mathrm{~cm}$ from AOG with the mixed application of cowdung + MOC + poultry manure $\left(\mathrm{V}_{2} \mathrm{~T}_{7}\right)$, while the shortest fruit length $(2.14 \mathrm{~cm})$ and breadth $(1.71 \mathrm{~cm})$ were found from control $\left(\mathrm{T}_{0}\right)$. This might be due to the effects of different organic manures on germination, growth, flowering, fruiting and yields of strawberry plants. It was found that mixture of different organic manure application increases the length and breadth in strawberry fruit (Atefe et al., 2012). The highest fruit yield per hectare $(20.82 \mathrm{t})$ was also obtained from Festival with cowdung + MOC + poultry manure $\left(\mathrm{V}_{1} \mathrm{~T}_{7}\right)$, followed $17.45 \mathrm{t}$ from AOG with cowdung + MOC + poultry manure $\left(\mathrm{V}_{2} \mathrm{~T}_{7}\right)$, whereas the lowest yield per hectare $(6.12 \mathrm{t})$ was recorded from AOG with control $\left(\mathrm{V}_{2} \mathrm{~T}_{0}\right)$. In case of commercial cultivation, similar result was also found by Strike (1993). It was observed that the maximum TSS content $(10.08 \%)$ was recorded from strawberry cultivar AOG with cowdung $+\mathrm{MOC}+$ poultry manure $\left(\mathrm{V}_{2} \mathrm{~T}_{7}\right)$, followed by $9.40 \%$ in Festival with cowdung $+\mathrm{MOC}+$ poultry manure $\left(\mathrm{V}_{1} \mathrm{~T}_{7}\right)$, while the minimum TSS content $(4.15 \%)$ was found from Festival with control $\left(\mathrm{V}_{1} \mathrm{~T}_{0}\right)$. Use of organic manures significantly increased levels of organic acids (malic and citric acid), sugars (fructose, glucose and total sugars) (Shiow and Shin-Shan, 2002), soluble solids and insoluble solids (Federico et al., 2007). In addition, due to the higher availability of macro and micronutrients and characters controls by genetic factors, sweetness of AOG strawberry cultivar was increased with the application of different mixed manures.

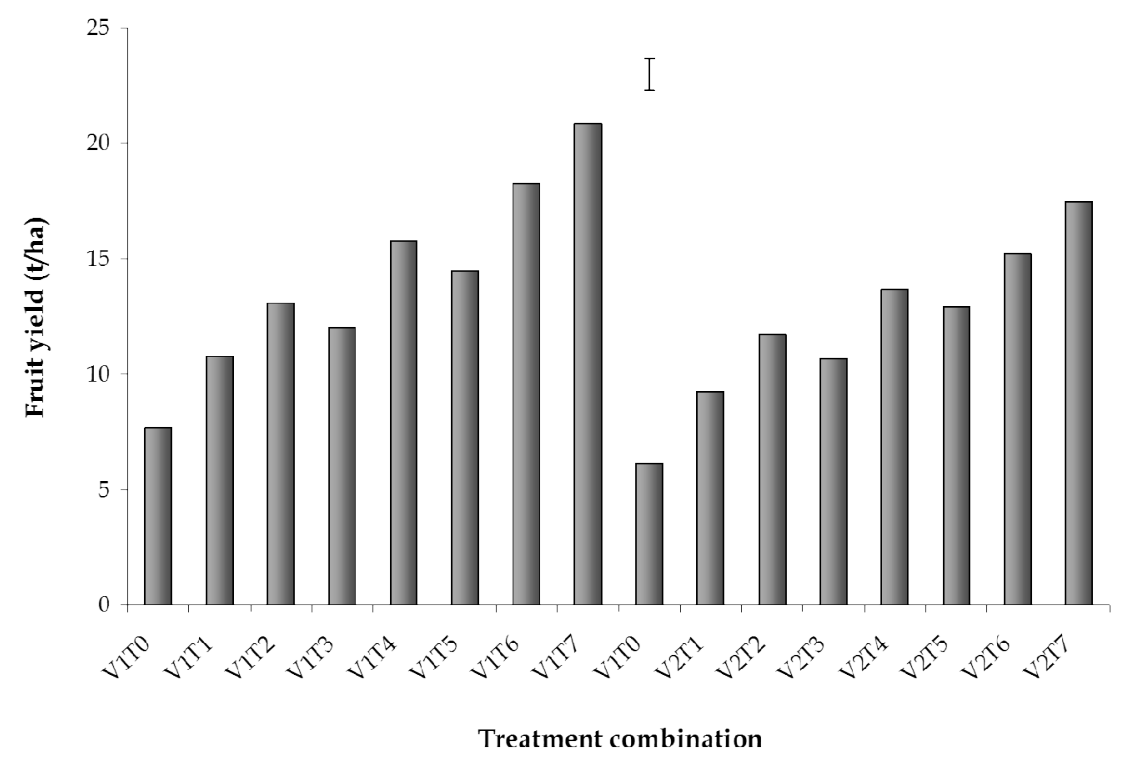

Fig. 3. Combined effects of variety and organic manures on fruit yield (t/ha) of strawberry. The vertical bar represents LSD at $5 \%$ level of probability

\section{Conclusions}

From the above results, it can be concluded that the cultivar RU-1 (Festival) along with combined application of cowdung + MOC + poultry manure found to be most effective in respect of vegetative growth and yield, while cultivar RU-2 (AOG) along with combined application of cowdung + MOC + poultry manure was better in respect of sweetness of strawberry. 


\section{References}

Abebe, G. 2001. Effect of Manure on Some Physicochemical Properties of Calcareous Soil, Yield and Quality of Cowpea [Vigna unguiculata (L.) Walp.] Under greenhouse conditions. M.S. Thesis, University of Jordan, Amman, Jordan.

Abu-Zahra, T.R. and Tahboub, A.A. 2008. Effect of Organic Matter Sources on Chemical Properties of $\square$ the Soil and Yield of Strawberry under Organic Farming Conditions. World Applied Sciences Journal, 5(3): 383-388.

Asami, D.K., Hong, Y.J. Barrett, D.M. and Mitchell, A.E. 2003. Comparison of the total phenolic $\square$ and ascorbic acid content of freezedried and air- $\square$ dried marionberry, strawberry and corn grown using conventional, organic and sustainable agriculture practices. Journal of Agriculture and Food Chemistry, 51: 12371241.

Atefe, A., Tehranifar, A., Shoor, M. and Davarynejad, G. H. 2012. Study of the effect of vermicompost as one of the substrate constituents on yield indexes of strawberry. Journal of Horticultural Science and Ornamental Plants, 4(3): 241-246.

Badiyala, R.P. and Bhutani, V.P. 1990. Effect of planting dates and spacing on yield and quality of strawberry cv. Tioga. South Indian Horticulture, 38(6): 295-296.

Boydston, R.A., Mojtahedi, H., Crosslin, J.M., Brown, C.R., Anderson, T. 2008. Effect of hairy nightshade (Solanum sarrachoides) presence on potato nematodes, diseases, and insect pests. Weed Science, 56: 15111154.

Cristina, L. and Jorge, D. 2011. The use of vermicompost in sustainable agriculture: Impact on plant growth and soil fertility. In: Soil Nutrients, Nova Science Publishers, Chapter 10, pp. 2-16.

Deksissa, T., Short, I. and Allen, J. 2008. Effect of soil amendment with compost on growth and water use efficiency of Amaranth. In: Proceedings of the UCOWR/NIWR annual conference: International water resources: challenges for the $21^{\text {st }}$ century and water resources education, July 22-24, 2008, Durham, NC.

El-Hamid, Aza, A.S., Abbou, A.A., Mansour, S.A.A., El-Sayed, A.A.A. 2006. Effect of some biofertilizers on yield and fruit quality of strawberry. Annals of Agricultural Sciences, 44(10): 251 ï 64.
Federico, A., Gutierrea, M., Borraz, J.S., Molina, J.A.M., Nafate, C.C., Archila, M.A., Llaven, M.A.O., Rosales, R.R. and Dendooven, L. 2007. Vermicompost as a soil supplement to improve growth, yield and fruit quality of tomato (Lycopersicum esculentum). Bioresource Technology, 98: 2781-2786.

Garg, S. and Bahla, G.S. 2008. Phosphorus availability to maize as influenced by organic manures and fertilizer $\mathrm{P}$ associated phosphatase activity in soils. Bioresource Technology, 99(13): 5773-5777.

Gliessman, S.R., M.R. Werner, J. Allison and Cochran, J. 1996. A comparison of strawberry plant development and yield under organic and conventional management on the central California coast. Biological Agriculture and Horticulture, 12(4): 327-338.

Gopalreddy, B. 1997. Soil health under integrated nutrient management in maize soybean cropping system. A PhD Thesis, Acharya N. G. Ranga Agricultural University, Rajendranagar, Hyderabad, Andhra Pradesh, India. pp. 125-173.

Grandy A.S., Porter G.A. and Erich, M.S. 2002. Organic amendment and rotation crop effects on the recovery of soil organic matter and aggregation in potato cropping systems. Soil Science Society of America Journal, 66: 1311 ï 1319.

Gutser, R., Ebertseder, T.H., Weber, A., Schraml, M., Schmidhalter, U. 2005. Short-term and residual availability of nitrogen after longterm application of organic fertilizers on arable land. Journal of Plant Nutrition and Soil Science, 168: 439101446.

Halvorsen, B.L., Holte, K., Myhestad, M.C.W., Bayikmo, J., Hvatium, E., Remberg, S.F., Wold, A.B., Haffner, K., Buugered, H., Andersen, L.F.,. Moskauy, J.G., Jacobs, D.R., JR and Biomhoff, R. 2002. Asystematic screening of total antioxidents in dietary plants. The Journal of Nutrition, 132: 461471.

Hasan, M. 2013. Response of strawberry germplasm to organic fertilizers. MS thesis, Department of Horticulture, Sher-e-bangla Agricultural University, Dhaka-1207. p. 130.

Hortynski, J. A., Zebrowska, J., Gawronski, J. and Hulewicz, T. 1991. Factors influencing fruit size in the strawberry (Fragaria $\times$ ananassa Duch.). Euphytica, 56: 67-74.

Kumar, N., Singh, H.K. and Mishra, P.K. 2015. Impact of Organic Manures and Biofertilizers on 
Growth, and Quality Parameters of Strawberry cv. Chandler. Indian Journal of Science and Technology, 8(15), DOI: 10.17485/ijst/2015/v8i15/51107

LaMondia, J.A., Elmer, W.H., Mervosh, T.L. and Cowles, R.S. 2002. Integrated management of strawberry pests by rotation and intercropping. Crop Protection, 21: 837-846.

Lindhard, H., Korsgaard, H. and Daugaard, H. 2000. Organic fruit production in Denmark. Department of Horticulture, Kirstinebjergvej 10, DK 5792 Aarslev, Denmark. Retrieved from:

http://www.certifiedorganic.bc.ca/rcbtoa/train ing/fr uit.htm

Makinde, E.A. and Ayoola, O.T. 2012. Comparative growth and yield of okra with cowdung and poultry manure. American-Eurasian Journal of Sustainable Agriculture, 6(1): 18-23.

Malone, G.W., Sims, J.T. and Geama, N. 1992. Quality and quantity of poultry manure produced under current management programme. Technical Report for the Delaware Department Natural Resources Environmental Control, Dover. pp. 11-50.

Mamta, K., Wani, A. and Rao, R.J. 2012. Effect of vermicompost on growth of brinjal plant (Solanum melongena) under field conditions. Journal on New Biological Reports, 1(1): 2528.

Morgan, L. 2006. Hydroponic strawberry production. A technical guide to the hydroponic production of strawberries. Suntec (NZ) Ltd., Tokomaru, New Zealand. pp. 43-69.

Nagavallemma, K.P., Wani, S.P., Stephane, L., Padmaja, V.V., Vineela, C., Babu, R.M. and Sahrawat, K.L. 2004. Vermicomposting: Recycling wastes into valuable organic fertilizer. Global theme on agrecosystems Report no. 8. Patancheru 502324, Andhra Pradesh, India. International Crops Research Institute for the Semi-Arid Tropics, 2(1): 1-20.

Norsworthy, J.K., and Meehan I.V. 2005. Herbicidal activity of eight isothiocyanates on Texas panicum (Panicum texanum), large crabgrass (Digitaria sanguinalis), and sickelpod (Senna obtusifolia). Weed Science, 53: 515-520.

Perkins-Veazie, P. 1995. Growth and ripening of strawberry fruit. Horticultural Reviews, 17: 267-297.

Pringle, G.J., Bussell, W.T and Perry, F. 2002. Strawberry growth and yield in response to the environment: inducing new production systems. Acta Horticulturae, 567: 423-426.

Rahman, M.M., Islam, M.N., Roni, M.Z.K., Gani, O. and. Jamal Uddin, A.F.M. 2018. Vermicompost and Mustard Oil Cake as an Alternative Fertilizer for Strawberry Production. International Journal of Business, Social and Scientific Research, 6(3): 78-84.

Reganold, J.P., Andrews, P.K., Reeve, J.R., CarpenterBoggs, L. and Schadt, C.W. 2010. Fruit and soil quality of organic and conventional strawberry agroecosystems. Public Library of Science one (PLoS ONE), 5(9): e12346.

Schopplein, E., Kruger, E., Rechner, A. and Hoberg, E. 2002. Analytical and sensory qualities of strawberry cultivars. Acta Horticulturae, 567: 805-808.

Sharma, R.R. 2002. Growing Strawberries. International Book Distributing Co. Chaman Studio Building, $2^{\text {nd }}$ Floor, Charbagh, Lucknow 226004 U.P. (India). p. 164.

Shiow, Y.W. and Shin-Shan, L. 2002. Composts as soil supplement enhanced plant growth and fruit quality of strawberry. Journal of Plant Nutrition, 25(10): 2243- 2259.

Shiow, Y.W., Galletta, G.T. and Comp, M.J. 1998. Mulches types effect fruit quality and composition of tow strawberry genotypes. Horticultural Science, 33(4): 636 - 640.

Sims, J.T. 1987. Agronomic evaluation of poultry manure as nitrogen source for conventional and no tillage corn. Agronomy Journal, 79: 563-582.

Strik, B.C. 1993. Growing strawberries in your home garden. Oregon State University Extension Service. EC1307. pp. 1-8.

Subbaiah, K., Sundararajan, S. and Raniperumal. 1985. Response of tomato and brinjal to varying levels of FYM and micronutrients under fertility status of soil. South Indian Horticulture, 33: 198-205.

Svensson, B., 2002. Organic growing of strawberries, with control of insects and mulching/fertilization. Acta Horticulturae, 567: 419-422.

Turemis, N., 2002. The effects of different organic deposits on yield and quality of strawberry cultivar Dorit (216). Acta Horticulturae, 567: 507-510.

Turkben, C., Seniz, V. and Ozer, E. 1997. An investigation on strawberry production in Bursa. Uludag University Faculty of Agriculture Journal, 11: 19. 
Vaughn, S.F., Palmquist, D.E., Duval, S.M. and Berhow, M.A. 2006. Herbicidal activity of glucosinolate-containing seedmeals. Weed Science, 54: 743-748.

Willrich, T., Jurmer, D.O. and Volk, V.V. 1974. Manure application guidelines for pacific northwest, ASAE paper No. 74-4601. American Society of Agricultural Engineers, St. Joseph, MI. 